together with uterine contractions and signs of fetal irritability. Relief was achieved with a pethidine injection. The relationship of the heparin injection to the uterine contraction was noticed but we decided to continue the treatment. After the second dose of heparin six hours later the patien immediately had he six hourminal pain which immediately had the same abdominal pain, whic was again relieved by pethidine. At this point we became sure that the uterine contractions were
due to the heparin injections. Heparin was stopped, due to the heparin injections. Heparin was stopped,
no other anticoagulants were given, and the patient no other anticoagulants wer
was treated conservatively.

So far as we know no such reaction to heparin has been reported before. We thought of a small retroplacental haemorrhage due to heparin as a possible cause of pain, but the speed of the reaction and the relatively small dose of heparin and absence of complications afterwards made this unlikely.-We are, etc.,

K. SHAKER

M. AMR

Amman Civil Hospital

NAIF A. SLIMAN

Amman, Jordan

\section{Treatment of Aspergillosis}

SIR,-We were interested in the studies of Drs. L. J. R. Milne and G. K. Crompton (28 September, p. 803) on the in-vitro action of emetine on strains of aspergilli, as we have also studied the effect of emetine on fungi.

Abd-Rabbo ${ }^{1}$ reported the anti-fungal effect of dehydroemetine in two cases of tinea favosa; and Abd-Rabbo and Yusef reported in-vitro action against Microsporum gypseum and Thielavia sepedonium. Jesiotr $^{3}$ reported the inhibitory action of emetine against a single strain of Nocardia as:eroides and one of Cryptococcus neoformans. Because of these reports we have studied one strain of $N$. asteroides and eight strains of Candida albicans in addition to two strains of Aspergillus fumigatus.

The minimum inhibitory concentration of each strain was determined by an agardilution method or tube dilution. The studies of Child $\epsilon \cdot a l .^{+}$showed that emetine accumulates in rat lung and that levels up to $17 \cdot 7 \mu \mathrm{g} / \mathrm{g}$ wet tissue were obtained. In view of these findings we have tested our strains of Candida at levels up to only 32 $\mu \mathrm{g} / \mathrm{ml}$ and the other organisms at levels up to $200 \mu \mathrm{g} / \mathrm{ml}$. None of the organisms showed inhibition of growth at these concentrations.

We support the views expressed by Drs Milne and Crompton and wish to add that emetine would appear to be of no value in the treatment of infections with the other organisms we have studied.-We are, etc.

Department of Virology

R. H. GEORGE

Medical Schoo

Department of Bacteriology

Queen Elizabeth Hospital,

Birmingham

Abd-Rabbo, H., Lancet, 1964, 2, 1013.

Abd-Rabbo, H., and Yusef, H. M., fournal of Tropical Medicine and Hygiene, 1966, 69, 51.

Jesiotr, M., Scandinavian fournal of Respiratory

Disease, 1973, 54, 326

Pharmacology, 1964, 16, 65.

\section{Use of Intravenous Urography}

SIR,-I believe that the conclusions drawn by Dr. R. Kreel and his colleagues (5 October, p. 31) on the use of intravenous urography (I.V.U.) in the investigation of haematuria are ill-founded and potentially dangerous. It is proposed that "a considerable saving in radiological resources might be made by ensuring that in cases of this sort a midstream specimen of urine is examined followed by cystoscopy." Presumably it is suggested that if these two investigations are normal the I.V.U. can be omitted.

Surely one of the features of urological malignancies is that they bleed one day and not the next? Certainly the absence of microscopic haematuria does not exclude neoplasm. If we are to change our practice and do cystoscopy before I.V.U. where does this leave us? If the bladder is normal we need an I.V.U. to exclude upper tract neoplasia, and if cystoscopy shows a bladder tumour we need to know if there is upper tract dilatation or co-existing urothelia malignancy in the renal pelvis or ureter. Worse still, if the subsequent I.V.U. shows no contrast medium excretion on one side the cystoscopy must be repeated to perform retrograde pyelography or ascending ureterography.

If urological malignancy is to be detected at an early and curable stage I believe that every case of haematuria must be carefully and methodically investigated. I.V.U. provides the basic fundamental information on the urinary tract on which supplementary special investigations may be selected if necessary. Attempts to short-circuit this wミll-es:ablished diagnostic routine in an attempt to save "radiological resources" are likely to be made at the expense of considerable clinical confusion, which in time is likely to lead to the loss of a patient's life owing to delay in the diagnosis of curable cancer.-I am, etc.,

Royal Marsden Hospital,

W. F. HENDRY

London S.W.3

\section{Alpha-adrenoceptor-blocking Drugs in} Asthma

SIR,-We were interested to read the report by Professor S. Bianco and others of the prevention of exercise-induced asthma by an alpha-adrenoceptor-blocking drug, in doramin (5 October, p. 18). Following ou demonstration of a significant reduction in histamine-induced asthma by an alphareceptor-blocking drug, thymoxamine, which has little antihistaminic activity, ${ }^{2}$ we have been interested in the possible role of alpha-receptors in the bronchial muscle in the pathogenesis of bronchoconstriction in asthma.

Some years ago Szentivanyi ${ }^{3}$ postulated that bronchial asthma might result when there is an imbalance between bronchial beta - receptors (bronchodilator) and bronchial alpha - receptors (bronchoconstrictor). If this were so enhanced bronchodilatation might occur when a betastimulant drug is given concurrently with an alpha-blocking drug. We have recently completed experiments where this hypothesis has been tested using aerosol salbutamol with intravenous indoramin or thymoxamine. We found that when salbutamol was given with either alpha-receptor-blocking drug a statistically significantly greater increase in the forced expiratory volume in one second $\left(F E V_{1}\right)$ was obtained than with salbutamo alone, whereas the alpha-blocking drugs alone had no greater intrinsic bronchodilator ctivity than placebo.

These results will be published in detail later but meantime we feel that these observations have possible therapeutic implications. It has been shown in vitro tha patients with severe asthma have high leucocytic adenylate cyclase activity. This activity was not further increased by isoprenaline alone or by an alpha-blocking drug alone (thymoxamine) but was increased when isoprenaline and thymoxamine were given together." Patients with severe asthma-or status asthmaticus-are characteristically unresponsive to betaadrenoceptcr-stimulant drugs and may remain so for a period even when large doses of corticosteroids are given parenterally. Is this possibly because the alpha-adrenoceptors are more active than normally? There is evidence that this is the case in human bronchial muscle exposed to bacterial endotoxins in vitro. ${ }^{5}$ Since bacterial infection is often a precipitating cause of severe asthma it would seem reasonable to give such patients an alpha-receptor-blocking drug, such as thymoxamine or indoramin, intravenously in an attempt to restore rapidly sensitivity of the beta-receptors to betaadrenoceptor-stimulant drugs. We have done this in a small number of cases and have seen this beneficial effect in some but not all patients.-We are, etc.,

\section{K. N. V. PALMER J. GADDIE C. SKINNER}

Department of Medicine

University of Aberdeen,

1 Gaddie, J., et al., British fournal of Diseases of the Chest, 1972, 66, 141. Gaddie, J., Skinner, Lancet, 1972, 2. 657

3 Szentivanyi, A., fournal of Allergy, 1968, 42, 203 Alston, W. C., Patel, K. R., and Kerr, J. W. British Medical fournal, 1974, 1, 90. te Medical fournal, 1971 pl. vol. 47, P. 120.

\section{Chemoprophylaxis against Tuberculosis}

SIR,-Permit me to add a footnote as a complementary paragraph to your leading article (12 October, p. 63) as this is a subject which interests many of your readers both at home and abroad.

Babies born of mothers with open tuberculosis incur the obvious risk of infection if breast-fed, or alternatively an equally severe and often fatal gastroenteritis (in developing countries) if not so breast-fed and looked after by the mother. In such cases it is possible to: (1) allow the mother to breastfeed her baby; (2) give the baby isoniazid chemoprophylaxis; and (3) immunize the baby with isoniazid-resistant B.C.G. vaccine. ${ }^{1}-\mathrm{I}$ am, etc.,

E. E. Vella

Department of Pathology,

Royal Army Medical College,

1 Hendrickse, R. G., in Management and Treatment of Tropical Diseases, ed. B. G. Maegraith
and H. M. Gilles, p. 200. Oxford, Blackwell, and 1971 .

Variability in Response to Drugs

SIR,-Professor Michael D. Rawlins in his admirable article (12 October, p. 91) surveys some of the factors which determine the response to drugs. He refers in particular 